\title{
The First Anatomically Modern Humans from South-Eastern Europe. Contributions from the Buran-Kaya III Site (Crimea)
}

\author{
Les premiers hommes anatomiquement modernes du Sud-Est de l'Europe. Apport du site \\ de Buran-Kaya III (Crimée).
}

\author{
S. Prat · S. Péan · L. Crépin · S. Puaud · D. G. Drucker $\cdot$ M. Lázničková-Galetová · J. Van der Plicht $\cdot$ H. Valladas $\cdot$ \\ C. Verna $\cdot$ M. Patou-Mathis $\cdot$ M. Lebon $\cdot$ A. Yanevich \\ Received: 1 June 2018; Accepted: 3 October 2018 \\ (C) Société d'Anthropologie de Paris et Lavoisier SAS 2018
}

\begin{abstract}
The arrival of modern humans into Europe, their dispersal and their potential interactions with Neanderthals are still in debate. Whereas the first appearance of anatomi-
\end{abstract}

S. Prat $(\bowtie) \cdot$ S. Puaud $\cdot$ M. Lázničková-Galetová $\cdot$ C. Verna

M. Lebon

UMR 7194 (HNHP), MNHN/CNRS/UPVD,

Association Sorbonne Université, Musée de l'Homme,

Palais de Chaillot, 17 place du Trocadéro, 75016 Paris, France

e-mail : sandrine.prat@mnhn.fr

S. Péan · L. Crépin · M. Patou-Mathis

UMR 7194 (HNHP), MNHN/CNRS/UPVD,

Association Sorbonne Université, Institut de Paléontologie

Humaine, 1 rue René Panhard, 75013 Paris, France

D. G. Drucker

Fachbereich Geowissenschaften, Forschungsbereich

Paläobiologie, AG Biogeologie, Universität Tübingen,

Hölderlinstr. 12, 72074 Tübingen, Germany

Senckenberg Centre for Human Evolution and

Palaeoenvironment (HEP) an der Universität Tübingen,

Hölderlinstr. 12, 72074 Tübingen, Germany.

M. Lázničková-Galetová

Moravian Museum, Zelný trh 6, 65937 Brno, Czech Republic

and

Hrdlicka Museum of Man, Faculty of Science Charles University, Viničná 1594/7,128 00 Praha, Czech Republic

J. Van der Plicht

Center for Isotope Research, Groningen University, Groningen/

Faculty of Archaeology, Leiden University, Leiden, the

Netherlands

H. Valladas

Laboratoire des Sciences du Climat et de l'Environnement/IPSL, CEA-CNRS-UVSQ, Gif-sur-Yvette, France

A. Yanevich

Institute of Archaeology, National Academy of Sciences

of Ukraine, Heroiv Stalingrada 12, 04210 Kyiv, Ukraine. cally modern humans in Western Europe seems to be well understood, the situation is quite different for Eastern Europe, where data are more scarce. The Buran-Kaya III site in Crimea is of key importance to understand the colonization of Europe by anatomically modern humans and their potential contemporaneity with the last Neanderthal occupations. The new radiocarbon dated sequence shows that no Neanderthal settlement existed after $39 \mathrm{ka}$ cal BP and casts doubt on the survival, as previously proposed, of Neanderthal refuge zones in Crimea $28 \mathrm{ka}$ BP ago (34-32 ka cal BP). The human remains from Buran-Kaya III, directly dated to $32450+250 /-230$ BP (layer 6-2) and 31900+/-220 BP (layer 6-1) (37.1-35.7 ka cal BP and 36.3-35.2 cal BP respectively), represent some of the oldest evidence of anatomically modern humans in Europe in a unique welldocumented archaeological context (Gravettian). Furthermore, the specimens from layer 6-1 represent the oldest Upper Palaeolithic modern humans from Eastern Europe with evidence of post-mortem treatment of the dead.

Keywords Anatomically modern humans $\cdot{ }^{14} \mathrm{C}$ dates . Neanderthals $\cdot$ Crimea $\cdot$ Upper Palaeolithic.

Résumé L'arrivée des premières populations d'hommes anatomiquement modernes en Europe et leurs interactions avec les Néandertaliens font l'objet de nombreux débats. Si cette histoire semble bien comprise en Europe occidentale, il en est différemment en Europe orientale où la documentation est plus parcellaire. Le site de Buran-Kaya III, en Crimée, apparaît comme un site majeur grâce à l'apport de nouvelles données chronologiques relatives aux dernières occupations néandertaliennes, et à la présence de restes attribués aux hommes anatomiquement modernes directement datés à $32450+250 /-230$ BP (niveau 6-2) et $31900+/-220$ BP (niveau 6-1) (37,1-35,7 ka cal BP and 36,3-35,2 ka cal BP respectivement). Les nouvelles datations radiocarbones 
montrent que les populations néandertaliennes n'étaient plus présentes en Crimée après $39 \mathrm{ka}$ cal BP et remettent en question l'existence, qui était proposée jusqu'à alors, d'une zone refuge pour ces populations en Crimée il y a 28 ka BP (34-32 ka cal BP). Par ailleurs, les restes humains de Buran-Kaya III sont parmi les plus anciens hommes anatomiquement modernes d'Europe orientale et, fait exceptionnel, dans un contexte culturel bien documenté (techno-complexe gravettien). Les individus de la couche 6-1 sont, en outre, les plus anciens hommes modernes du Paléolithique supérieur d'Europe orientale à témoigner d'un traitement post-mortem complexe des défunts.

Mots clés Hommes anatomiquement modernes · datations ${ }^{14} \mathrm{C} \cdot$ Néandertaliens $\cdot$ Crimée $\cdot$ Paléolithique supérieur.

\section{Introduction}

Knowledge about the populations who were living in Europe during the first part of the Upper Palaeolithic (40,000-25,000 years ago) has recently made advances thanks to the discovery of new anthropological remains and archaeological sites, the building of a new chronological framework [e.g. 1-23] and new palaeogenetic and palaeogenomic data [e.g. 24-32]. These new data and results have revealed high cultural, morphological and genetic diversity, which coincides with the presence of three distinct hominin taxa in Eurasia at the

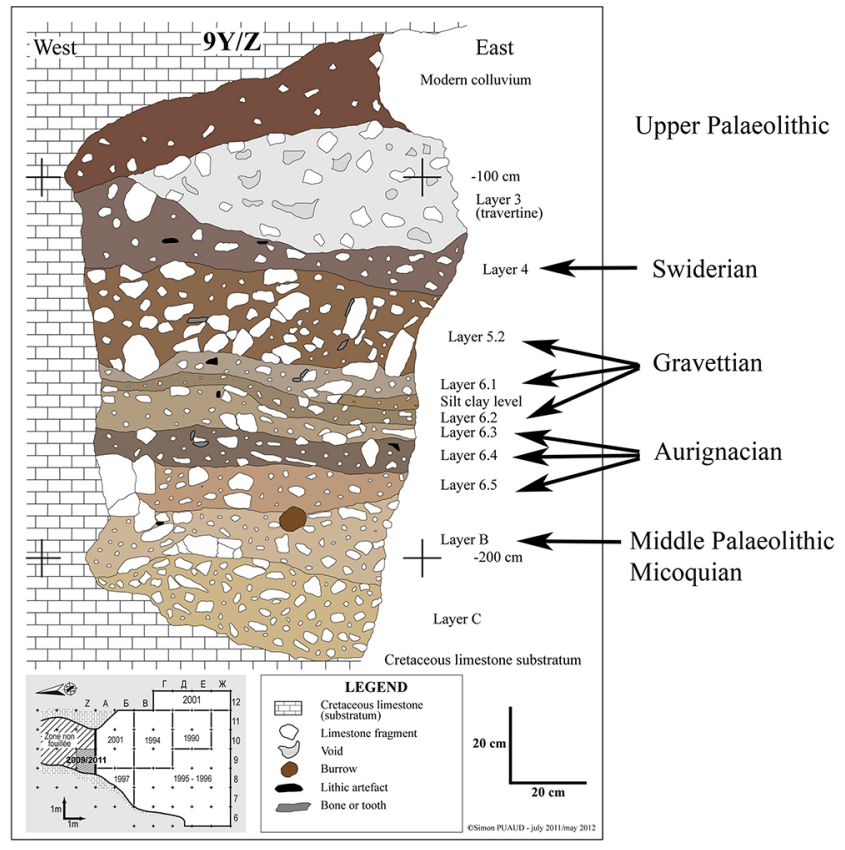

Fig 1 Stratigraphic framework of Buran-Kaya III. Infographics S. Puaud modified from [44]. Cadre stratigraphique du site de BuranKaya III / Infographie S. Puaud modifié d'après [44] beginning of the Upper Palaeolithic: "the last Neanderthals, the Denisovans and the first anatomically modern humans".

However, the arrival of modern humans in Europe, their dispersal along with associated Early Upper Palaeolithic cultural tradition(s) and their potential biological and/or cultural interactions with Neanderthals are still in debate. Whereas the first appearance and dispersal of anatomically modern humans in Western Europe seems to be well understood, the situation is quite different for Eastern Europe, where data are more scarce.

The Buran-Kaya III site in Crimea, which has yielded a rich Middle and Upper Palaeolithic archaeological sequence (Figure 1) and many human remains in situ is a key site in this respect [7,35-37]. Based on previous radiocarbon dating of the Middle Palaeolithic layer (Micoquian, Kiik-Koba type, layer B, 28.5 ka BP, i.e. 32.8-32.1 ka cal BP), Crimea was often considered as the area showing the most recent Neanderthal occupation in Eastern Europe [36,38,39].

An assessment of the human remains discovered at Buran-Kaya III and the new chronological and environmental framework obtained for this site offer important insights into the first modern human settlements in Europe. This site is also important for the discussion of the possible chronological overlap between Neanderthals and modern humans in this region.

The Buran-Kaya complex of sites is located in the eastern part of Crimea, along the middle reaches of the Burulcha river in the Belogorsk region (4 km south from the city of Aromatne). Buran-Kaya III was discovered in 1990 by A. Yanevich and excavated until 2001 by a team directed by A. Yanevich (Palaeolithic to Neolithic layers) and A. Marks (Middle and Early Upper Palaeolithic layers), with the participation of V. Chabai, Y. Demidenko, K. Monigal, M. Otte and Y. Yamada [35]. New fieldwork was conducted by A. Yanevich and S. Péan (2009-2011).

\section{Cultural context and settlement pattern in Buran-Kaya III}

More than 28,000 lithic remains were discovered in the Gravettian layers 6-2, 6-1 and 5-2 during the 2001 field season $[40,41]$. Retouched tools represent $5.1 \%, 3.7 \%$ and $3.2 \%$ of the lithic assemblage for layers 6-2, 6-1 and 5-2, respectively. They exhibit a broad spectrum of tool types (e.g. burins, end-scrapers, backed microliths). Within the retouched group there is a high proportion of microliths $(74.6 \%, 87.2 \%$ and $77.1 \%$ for layers $6-2,6-1$ and $5-2$ respectively), which are an important component of the Gravettian Complex (Figure 2). The attribution of these layers $(6-2,6-1$ and 5-2) to the Gravettian tradition is free from material sedimentary overlap, as shown by the sedimentological and stratigraphic studies conducted during the 2001 and 2009 field seasons. 


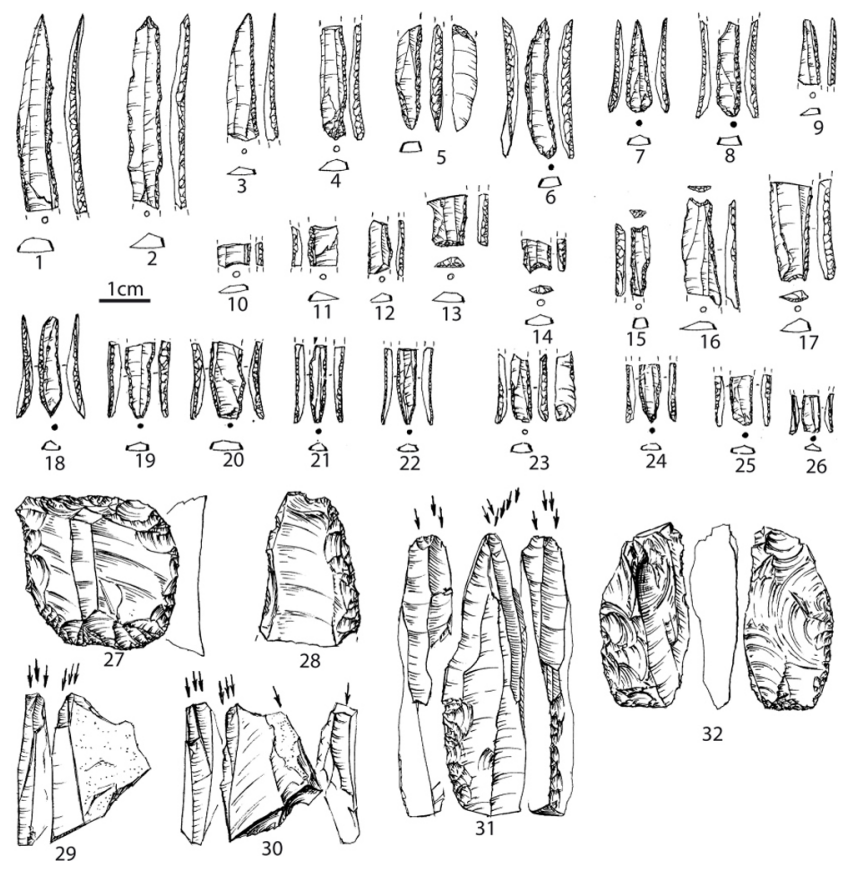

Fig. 2 Lithic industry from Buran-Kaya III, layer 6-1, modified from [41] / Industrie lithique de Buran-Kaya III, couche 6-1, modifié d'après [41]

There is continuity in the stratigraphic sequence from the lower layers (Aurignacian technocomplex: 6-5, 6-4, 6-3) to the upper layers (Gravettian technocomplex: 6-2, 6-1 and 52). In layers 6-2, 6-1 and 5-2, the lithic industries exhibit a high percentage of microliths (more than $80 \%$ ) and some microgravettes (Yanevich, 2014 [41]), which are consistent with the Gravettian technocomplex. Furthermore, lithic artefacts commonly associated with the Aurignacian technocomplex, such as Dufour and pseudo-Dufour blades [41], which are present in the immediately underlying layers 6$3,6-4$ and 6-5, were not observed in layers 6-2, 6-1 and 52 , further supporting the technical attribution of the lithics from these layers to the Gravettian.

The main raw material is a high-quality black or grey flint, whose main source is located $10-20 \mathrm{~km}$ northnorth-east of the site. The lithic industry of layers 6-2, 6-1 and 5-2, which is attributed to the Gravettian tradition, seems to reflect a pattern of either long-term occupation or recurrent settlement episodes. All phases of lithic exploitation are present, including several completely reduced cores and a high proportion of débitage, as well as production and resharpening of formal tools.

Regarding the bone industry, more than 60 bone tools have been discovered in layers 6-2, 6-1 and 5-2, including projectile points, awls, arrowheads, and assegai points [41]. The absence of waste from their manufacture indicates that the bone industry was imported. In combination with the zooarchaeological data [42], this evidence with suggests a pattern of recurrent short-term occupation, for example for seasonal hunting or temporary butchery camps. This may have been associated with the procurement and processing of small or medium-sized mammals, such as Saiga antelope, which is the main game species found at Buran-Kaya III. Red fox, polar fox and hare were also eaten and their fur removed and used [42]. Several personal ornaments made of mammoth ivory have been identified in layer 6-1 (study undertaken by Martina Lázničková-Galetová). The absence of this taxon in the faunal spectrum of the layer suggests that these items were also imported.

\section{Sedimentological and palaeoecological contexts}

The sedimentological infill is made up of diamicton layers with a small amount of sandy or loamy matrix with slightly rounded or angular autochthonous limestone fragments. These lithostratigraphic facies suggest that this sequence was formed in a periglacial environment corresponding to a cold and a dry period, with more temperate conditions between layer 6-2 and layer 6-1 illustrated by a thin sandy clay [43]. Analyses of the sedimentological data and faunal remains show that from the Aurignacian layer 6-4 to the lower Gravettian layer 6-2, the climate was cold and dry, in an open steppe environment, probably without forested areas. In the three Gravettian layers (6-2, 6-1, 5-2), the same mammalian taxa are predominant: saiga antelope, hare, and red and polar foxes $[42,44]$. In layers 6-1 and 62 , the faunal assemblage shows the most diversified spectra in the stratigraphic sequence, with reindeer and woolly rhinoceros present in layer 6-1 and marmot in layer 6-2. This was followed by a cold event, during which the climate became drier and cooler with less contrast between seasons. The environment was open, with a few small wooded areas around the site: brown bear, wild cat, red deer and mustelids [44] are present. The sedimentological data with the occurrence of wild cat and brown bear show that the bottom of layer 6-1 is marked by a wet event [42]. The palynological $[45,6]$ and micromammal analyses reveal a steppe environment with a climate evolving towards increasing aridity, in a similar pattern to that recorded in the mammalian sequence. It is interesting to note that the status of several species differs between archaeological layers: for instance, the status of red deer is symbolic in layer 6-2 (two perforated red deer canines) and nutritional in the upper layers 6-1 and 5-2 [42]. The relatively continuous recurrent settlements in the Buran-Kaya III rock shelter can be linked to the particular location of the site in a transitional area between the steppes and the Crimean Mountains, where different biotopes would occur: steppe, forest along the river bank and plateau. 


\section{Chronological context: new data}

A new chronological framework (Table 1) has recently been proposed [44]. Several AMS ${ }^{14} \mathrm{C}$ dating studies were undertaken in three laboratories: Groningen University (J. Van der Plicht), Laboratoire des Sciences du Climat et de l'Environnement, Gif-sur-Yvette/Saclay (H. Valladas) and Oxford University (A. Stuart). Seven bones were crossed-dated (i.e. analysed in two laboratories) [44]. The coherence of the results with the stratigraphic sequence reinforces the reliability of the chronological framework of Buran-Kaya III. The Late Middle Palaeolithic settlements (Micoquian, layer B) range from $35,390+290 /-270$ to $37,700 \pm 900 \mathrm{BP}$ (43,545 and 39,520 cal BP) [44]. These new ${ }^{14} \mathrm{C}$ dates [44] show that no Neanderthal settlement existed after $39 \mathrm{ka} \mathrm{cal}$ $\mathrm{BP}$, and cast doubt on the survival, as previously proposed, of Neanderthal refuge zones in Crimea until $28 \mathrm{ka}$ BP $(28,520 \pm 460$ BP $($ OxA-6674) and 28,840 \pm 460 BP
(OxA-6673), i.e. 31.4-33.9 ka cal BP [36, 38]). Recent papers on the Neanderthal disappearance [19] and the Neanderthal refuge zones claimed in Zaffaraya (Spain) [17], Vindija (Croatia) [47], Mezmaiskaya and Ortvale Klde (northern and southern Caucasus) $[14,48]$ came to the same conclusions.

Two human cranial fragments from the Gravettian layers were dated to $32,450+250 /-230 \mathrm{BP}$, i.e. $37.1-35.7 \mathrm{ka}$ cal BP, in layer 6-2 (GrA-50457) [44] and 31,900+240/-220 BP, i.e. 36.3-35.2 ka cal BP, layer 6-1 (GrA-37938) [43]. The Gravettian specimens from Buran-Kaya III, together with Peștera cu Oase in Romania (Oase 1: 34,290 +970/-870 BP, i.e. 36.47-41.07 ka cal BP, GrA-22810, [2]) and Kostenki in Russia (Kostenki 14: 33,250 +/-500 BP, i.e. 38.68-36.26 ka cal BP [5]), represent the earliest occurrences of anatomically modern humans in Eastern Europe. We can note the later occurrence of anatomically modern humans in Western Europe, as in Goyet Q116-1 (30,880 +170-160 BP,

Table $1 \mathrm{New}{ }^{14} \mathrm{C}$ dates of the Buran-Kaya III sequence (from layer B to 5-2), modified from [44]. The dates were calibrated using OxCal v4.3.2 software based on the IntCal13 calibration data set [56]. The calibrated dates are rounded to $5 .{ }^{\#}$ : the fox bone is considered as intrusive in the stratigraphy.* GrA_53939 is considered as an outlier [44] / Nouvelles datations Carbone 14, site de Buran-Kaya III (niveau B à 5.2), modifiées d'après [44]. Calibration à partir du logiciel OxCal v4.3.2 sur la base de la calibration IntCal13 [56]. Calibration arrondie au 5 le plus proche. ${ }^{*}$ : le spécimen de renard est considéré comme intrusif dans la stratigraphie* GrA_53939 est considérée comme une donnée aberrante [44].

\begin{tabular}{|c|c|c|c|c|c|c|c|c|c|}
\hline \multirow[t]{2}{*}{ Laboratory Code } & \multirow[t]{2}{*}{ Layer } & \multirow[t]{2}{*}{ Culture } & \multirow[t]{2}{*}{ Species } & \multirow{2}{*}{$\begin{array}{l}{ }^{14} \mathrm{C} \\
\text { (BP) }\end{array}$} & \multirow[t]{2}{*}{$\sigma(+)$} & \multirow[t]{2}{*}{$\sigma(-)$} & \multirow[t]{2}{*}{$\mathrm{C} / \mathrm{N}$} & \multicolumn{2}{|c|}{ cal BP $(2 \sigma)$} \\
\hline & & & & & & & & low & high \\
\hline OxA-25670 & 4 & Swiderian & Saiga tatarica & 10040 & 45 & 45 & 3.4 & 11765 & 11325 \\
\hline GrA-50461 & & & Saiga tatarica & 10010 & 60 & 60 & - & 11755 & 11270 \\
\hline GifA-11219 / SacA-25135 & & & & 10050 & 70 & 70 & & 11945 & 11275 \\
\hline GrA-47316 & $5-2$ & Gravettian & Mammal & 30100 & 180 & 170 & 3.6 & 34530 & 33820 \\
\hline GifA-11222 / SacA-25139 & & & & 33790 & 880 & 880 & & 40345 & 36140 \\
\hline GifA-80186 / SacA-12265 & & & Vulpes vulpes \# & 24070 & 260 & 260 & 3.5 & 28665 & 27700 \\
\hline GrA-53942 & $6-1$ & & Saiga tatarica & 29640 & 170 & 160 & 3.3 & 34110 & 33515 \\
\hline OxA-25669 & & & & 32200 & 450 & 450 & & 37530 & 35100 \\
\hline GifA-10021 / SacA-19018 & & & Cervus elaphus & 31320 & 820 & 820 & 3.3 & 37560 & 33870 \\
\hline GifA-11216 / SacA-25133 & & & Saiga tatarica & 31530 & 670 & 670 & 3.4 & 37245 & 34170 \\
\hline GrA-37938 & & & Homo sapiens & 31900 & 240 & 220 & 3.3 & 36310 & 35240 \\
\hline GrA-50460 & $6-2$ & & Saiga tatarica & 29440 & 190 & 180 & 3.3 & 34010 & 33225 \\
\hline GrA-50457 & & & Homo sapiens & 32450 & 250 & 230 & 3.1 & 37110 & 35725 \\
\hline GrA-40485 & $6-3$ & Aurignacian & Equus cf.caballus & 34050 & 260 & 240 & 3.3 & 39195 & 37860 \\
\hline GifA-80181 / SacA 12260 & & & & 34910 & 950 & 950 & 3.3 & 41670 & 37350 \\
\hline GrA-53939* & & & Saiga tatarica & 29040 & 180 & 170 & 3.5 & 33670 & 32780 \\
\hline GifA-11221 / SacA-25138 & & & Saiga tatarica & 32740 & 780 & 780 & - & 38860 & 35170 \\
\hline GrA-48399 & $6-4$ & & Saiga tatarica & 31250 & 2450 & 1880 & - & 43430 & 31135 \\
\hline GifA-11220 / SacA-25137 & & & & 33350 & 830 & 830 & - & 39730 & 35770 \\
\hline GrA-47318 & $6-5$ & & Saiga tatarica & 32800 & 230 & 210 & 3.3 & 37700 & 36205 \\
\hline GifA-11217 / SacA-25134 & & & & 35900 & 1100 & 1100 & & 42500 & 38490 \\
\hline OxA-25879 & B & Micoquian & Saiga tatarica & 37700 & 900 & 900 & 3.2 & 43545 & 40520 \\
\hline GrA-47319 & & & Saiga tatarica & 35590 & 290 & 270 & 3.3 & 40950 & 39520 \\
\hline GifA-11218 / SacA-25135 & & & & 36500 & 1200 & 1200 & 3.3 & 43120 & 38775 \\
\hline
\end{tabular}


i.e. 35.16-34.43 ka cal BP, GrA-46175 [49]), in Russia as in Sunghir (Sunghir SI: $28,890+/-430$ BP, i.e. $33.87-31.77 \mathrm{ka}$ cal BP, OxA-X-2464-12; Sunghir SII: $30,100+/-550$, i.e. 35.28-33.18 ka cal BP, OxA-A-2395-6; Sunghir SIII: 30,000 +/-550 BP, i.e. 35.15-33.3 ka cal BP, OxA-X-2395-7; Sunghir SIV: $29,820+/-280$ BP, i.e. $34.48-33.49 \mathrm{ka}$ cal BP, OxA-X-2462-52 [5 50]) and in the Czech Republic as in Dolní Věstonice (Dolní Věstonice 16, associated with the Gravettian tradition: $25,740+/-210$ BP (on charcoal), i.e. $30.57-29.390 \mathrm{ka}$ cal BP, GrN-15277 [51]). Although radiocarbon dates older than $30 \mathrm{ka} \mathrm{BP}$ are mostly associated with the Aurignacian (e.g. [9,37,52]), other Gravettian settlements of this age are known, as for example in Moldova $\mathrm{V}$, layer 5, Ukraine (29,650 +/- 1,1320 BP [53]), Willendorf II, layer 5, in Austria (30,500+900-800 BP [54]), and Obłazowa cave in Poland (31,000 +/- 500 BP [55]).

\section{Human remains}

Among the sites located in the northern Black Sea region and yielding Middle to Upper Palaeolithic archaeological layers, Buran-Kaya III and Siuren I in Crimea (where a molar was discovered in Unit G [57]) are the only ones that have yielded anatomically modern human remains (Figure 3 ).
Crimea is also well-known for having particularly abundant Neanderthal remains (Kiik-Koba 1 and 2, e.g. [58-60]; Zaskal'naya V and VI [60,61], as well as Middle Palaeolithic industries that are usually attributed to Neanderthal occupation (e.g. [37,62-64]).

At Buran-Kaya III, two hundred human remains were discovered in three well-documented Upper Palaeolithic layers (6-2, 6-1, 5-2), which are securely attributed to the Gravettian cultural tradition. Here we report the main results we obtained for layer 6-1, which yielded the richest assemblage in terms of the number of human remains $(\mathrm{NR}=164)$, the number of individuals $(\mathrm{MNI}=5)$ and anatomical parts. These remains mostly consist of cranial parts $(\mathrm{NR}=114)$ and teeth $(\mathrm{NR}=41$, Table 2), representing $94 \%$ of the remains, whereas the postcranial skeleton is only represented by the remains of nine hand phalanges. At least 5 individuals have been identified on the basis of dental remains [59[years old; [10-14[ years old; [15-19[years old; [20-24[ years old and more than 30 years old [65].

The bones are highly fragmented with $45 \%$ of remains less than $2 \mathrm{~cm}$ in size, $48 \%$ between 2 and $5 \mathrm{~cm}$ and only $7 \%$ larger than $5 \mathrm{~cm}$. Due to this fragmentation, associated with the treatment of the dead (see below), taxonomical allocation can only be undertaken with the permanent teeth and the best preserved bone (occipital bone fragment BK3-55).

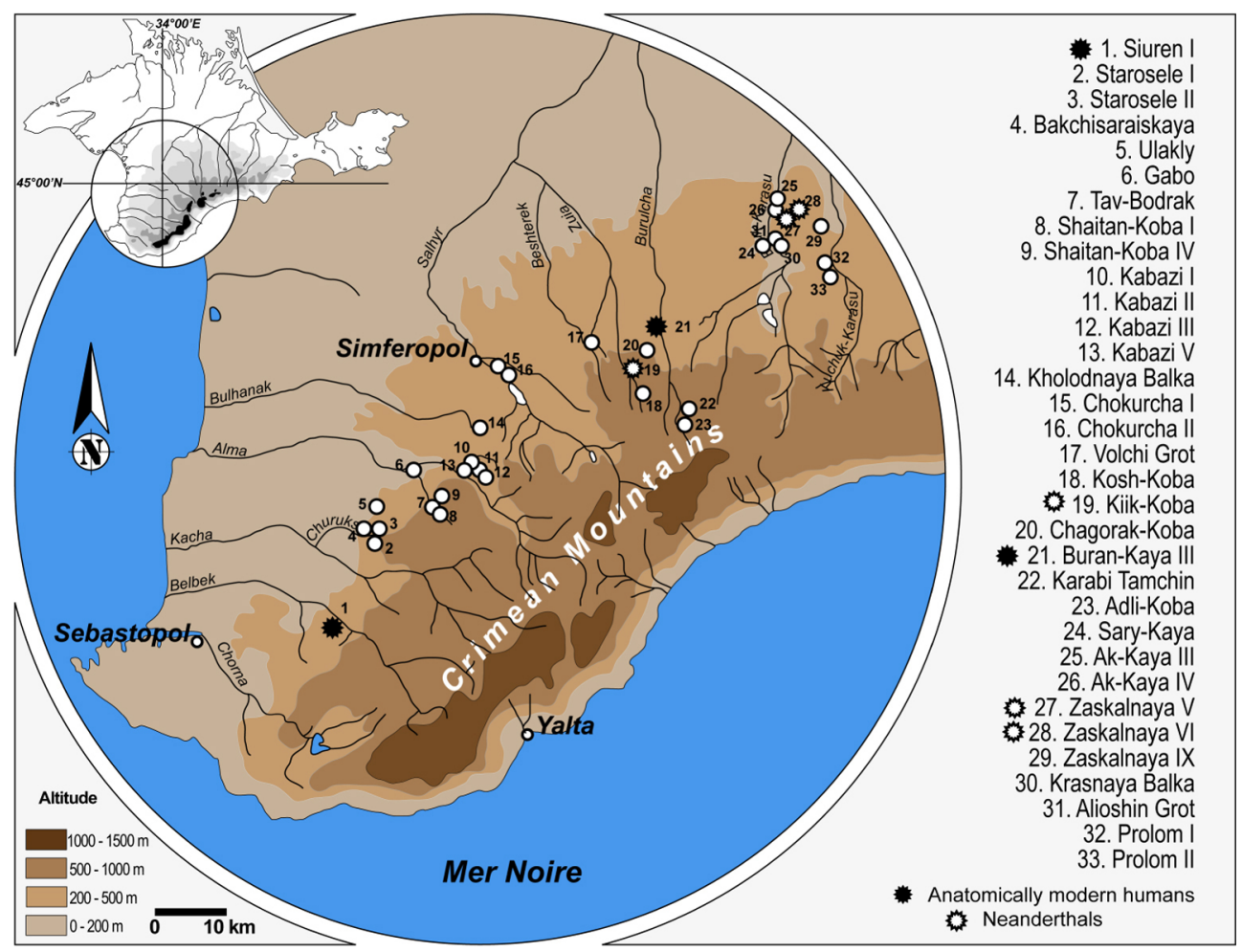

Fig. 3 Map of Middle and Upper Palaeolithic sites in Crimea with locations of Neanderthal and anatomically modern human remains, infographics S. Puaud /Carte des sites dates du Paléolithique moyen et supérieur de Crimée, localisation des sites où ont été découverts des restes d'hommes anatomiquement modernes et de Néandertaliens, infographie S. Puaud. 


\begin{tabular}{|c|c|c|c|}
\hline \multicolumn{2}{|l|}{ Lower dentition } & \multicolumn{2}{|c|}{ Upper dentition } \\
\hline di1 & & di1 & 1 \\
\hline $\operatorname{di} 2$ & & $\operatorname{di} 2$ & \\
\hline $\mathrm{dc}$ & 1 & $\mathrm{dc}$ & 1 \\
\hline $\mathrm{dm} 1$ & & $\mathrm{dm} 1$ & 1 \\
\hline $\mathrm{dm} 2$ & 1 & $\mathrm{dm} 2$ & \\
\hline Indet deciduous teeth & 1 & & \\
\hline I1 & 2 & I1 & 3 \\
\hline $\mathrm{I} 2$ & 3 & $\mathrm{I} 2$ & 1 \\
\hline $\mathrm{C}$ & 4 & $\mathrm{C}$ & 1 \\
\hline P3 & 2 & P3 & 2 \\
\hline P4 & 2 & $\mathrm{P} 4$ & 1 \\
\hline M1 & 1 & M1 & 3 \\
\hline M2 & 3 & M2 & \\
\hline M3 & 1 & M3 & 2 \\
\hline Indet permanent teeth & 4 & & \\
\hline
\end{tabular}

A series of morphological and metrical features distinguishes these human remains from Neanderthals. The dental remains exhibit traits that occur more frequently in anatomically modern humans than in Neanderthals, namely the symmetry observed in the occlusal outline, the lack of a welldeveloped metaconid and a transverse crest on the lower premolars; the lack of shovelling, labial convexity and the presence of well-developed lingual tubercles on the upper first incisors; the lack of a well-developed mid-trigonid crest and a large anterior fovea on the lower molars. Moreover, the occipital bones (e.g. BK3-55) do not present an occipital "bun" or a bilaterally transverse torus, which are considered as Neanderthal traits. Based on this combination of morphological features, the human remains from layer 6-1 at Buran-Kaya III are attributed to anatomically modern humans [43] (Figure 4, Table 3).

Based on the study of enamel dental hypoplasia (a nonspecific biomarker), the health of these individuals was good [65]. Physiological stress occurs only in the youngest individuals in their early childhood ( $\sim 3$ years). The observations

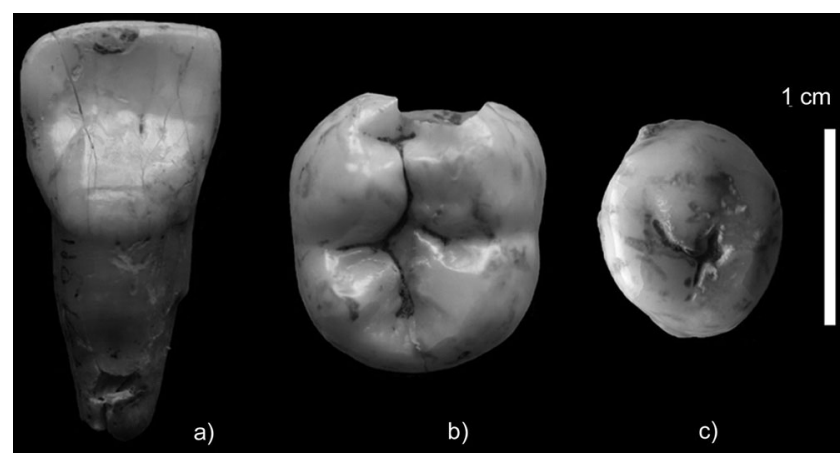

Fig. 4 Example of dental remains from layer 6-1. From left to right: a) right first upper incisor \#137; b) right lower second molar \#149; c) right lower second premolar \#133. Scale bar $=1 \mathrm{~cm}$, modified from [43] / Exemple de matériel dentaire de la couche 6-1, de gauche à droite : a) première incisive supérieure droite \#137, b) deuxième molaire inférieure droite \#149, c) deuxième prémolaire inférieure droite \#133, échelle $1 \mathrm{~cm}$, modifié d'après [43]

on the Buran-Kaya III materials are consistent with previous studies documenting the low frequency of enamel hypoplasia during the Early Upper Palaeolithic [67-71]. Our results confirm the low occurrence of dental pathologies, such as caries, as well as low levels of physiological stress during this period [65] (Figure 5).

\section{Reconstruction of the human diet}

The isotopic analyses of bone collagen from the human individuals revealed a diet mainly based on terrestrial resources with a preponderant role of mammoth meat in the protein intake (Figure 6), which contrasts with the zooarchaeological record [72]. Saiga antelope was found to be the dominant species in the mammalian assemblage at the site, while mammoth is only represented by one ornament at this site, which was dedicated to butchery activities and saiga antelope hunting over short periods of time [42]. Besides meat consumption, the plant component of the diet was higher than the $20 \%$ estimated for the late Neanderthals at the Spy

Table 3 Table of frequency of the dental traits recorded. Comparative data from [66] / Fréquences des caractères morphologiques dentaires. Données de comparaison [66].

\begin{tabular}{|llll|}
\hline & Neanderthals & $\begin{array}{l}\text { European Early Modern } \\
\text { Humans }\end{array}$ & Buran-Kaya III \\
\hline Shovelling Upper First Incisor & $91.7 \%(22 / 24)$ & $50 \%(6 / 12)$ & $0 \%(0 / 3)$ \\
Labial convexity Upper First Incisor & $95.8 \%(23 / 24)$ & $50 \%(6 / 12)$ & $0 \%(0 / 3)$ \\
Lower First Molar. Mid-trigonid Crest & $93.5 \%(29 / 31)$ & $0 \%(0 / 24)$ & $0 \%(0 / 1)$ \\
Lower First Molar. Well-developed anterior fovea & $88.6 \%(31 / 35)$ & $52.6 \%(10 / 19)$ & $0 \%(0 / 1)$ \\
Lower Second Molar. Well-developed anterior fovea & $96.2 \%(25 / 26)$ & $4.2 \%(1 / 24)$ & $0 \%(0 / 1)$ \\
\hline
\end{tabular}




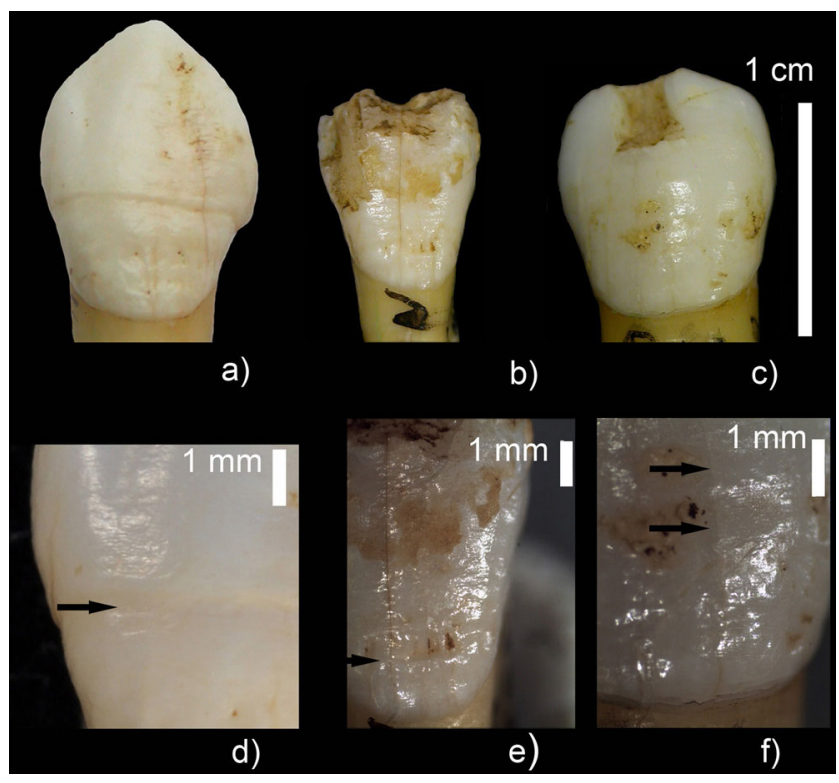

Fig. 5 Labial view of enamel hypoplasia in the dental sample from layer 6-1 at Buran-Kaya III. a) and d) lower canine \# 152; $\mathrm{b}$ and e) lower second incisor \# 138, c) and f) upper canine \#134. Top: overall view a, b, c; bottom: detailed view d, e, f. The arrows indicate the location of the hypoplasia, modified from [65] / Hypoplasie linéaire de l'émail dentaire, vue labiale. a) et d) canine inférieure \#152; b) et e) deuxième incisive inférieure ; c) et f) canine supérieure \#134. En haut, vue générale a, b c, en bas, vue de détail $d$, e, f. Les flèches indiquent la position des hypoplasies, figure modifiée d'après [65]

site in Belgium [73]. This suggests higher availability of plant resources in the context of Buran-Kaya III at a more southerly latitude. Interestingly, significant consumption of mammoth was inferred from the isotopic signature of late Neanderthals in western Europe [74,75], suggesting that this species had an important role in human subsistence in Europe over time and space.

\section{Anthropic modifications}

Among the human remains from layer 6-1 (2001, 2009 and 2010 field seasons), only a few bones $(\mathrm{NR}=14)$ exhibit human modifications, such as cut marks. Their morphology, location (in relation to muscle insertions) and distribution suggest two different processes: scalping evidenced on fronto-parietal fragments and disarticulation of the occipital and temporal bones (Figure 7). Three anthropogenic actions on human bodies can be hypothesized to explain the occurrence of these cut marks on several human remains: dietary and non-dietary cannibalism, or mortuary practices. In order to test these hypotheses, we undertook comparative taphonomical analy-

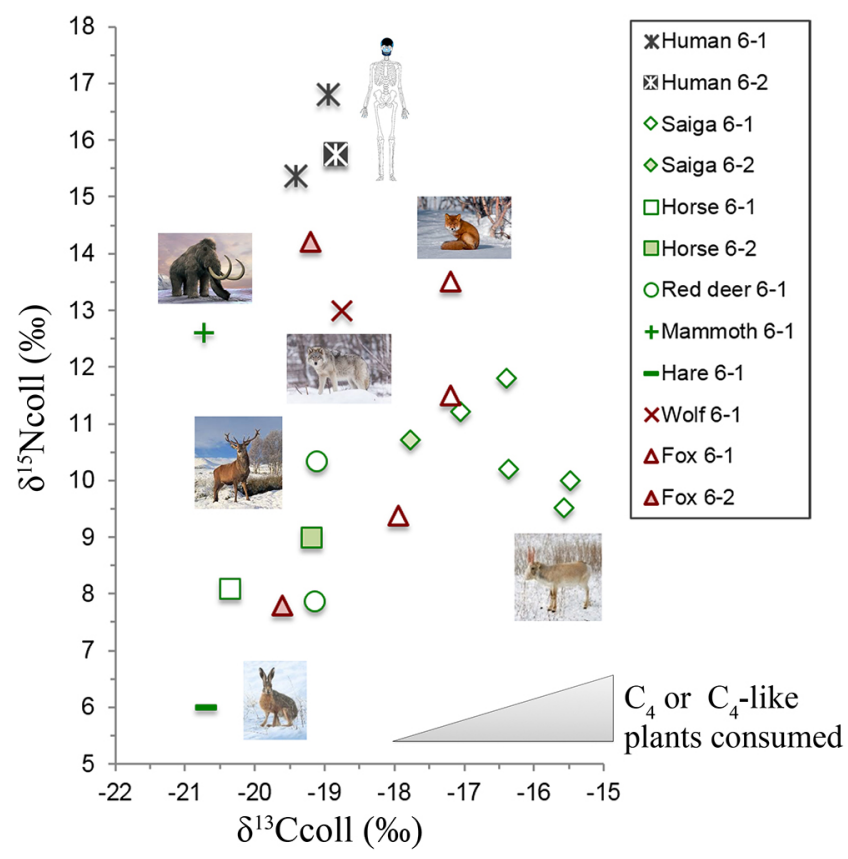

Fig. 6 Measured $\delta^{13}$ Ccoll and $\delta^{15}$ Ncoll values of herbivores (hare, horse, mammoth, saiga and red deer, in green) and anatomically modern humans, fox and wolf from layers 6-1 and 6-2 of BuranKaya III (in red), modified from [72]. The values are given in Table 2 in [72] / Données $\delta^{13}$ Ccoll and $\delta^{15} N$ coll des couches 6-1 et 6-2 $d u$ site de Buran-Kaya III, herbivore en vert (renard, cheval, mammouth, antilope saiga, cerf) et hommes anatomiquement modernes, renard et loup en rouge, modifiées d'après [72]. Les données sont illustrées dans le tableau 2 dans l'article de D. Drucker et collaborateurs [72]

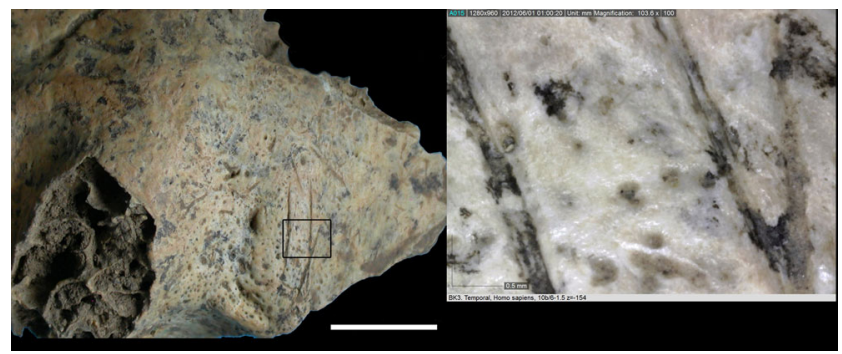

Fig. 7 Locations of the cut marks on the exocranial surface of a human right temporal bone \#56, layer 6-1. / Localisation des traces de découpe sur la surface exocrânienne, os temporal droit humain \#56, couche 6-1.

ses between the saiga antelope (the main game species) and the human remains, including the spatial distribution of the remains, skeletal representation and surface bone modifications. Our results show that the two taxa were not processed in the same way, and that the human skulls were intentionally selected in association with post-mortem treatments of the dead $[43,76]$. Consequently, the hypothesis of dietary 
cannibalism (as defined by Villa and collaborators [77]) is not supported by the data from Buran-Kaya III. Ritual cannibalism or a specific mortuary practice, such as post-mortem disarticulation of corpses for secondary disposal, are proposed as alternative scenarios. In addition, the presence of personal ornaments reinforces the hypothesis of symbolic behaviour and/or a specific ritual for these Gravettian individuals $[43,76]$. This represents the oldest evidence (at 36.9-35.5 ka cal BP) of complex treatment of the dead by anatomically modern humans in eastern Europe.

Anthropic treatment of human remains has been documented in modern humans in both the Aurignacian (e.g. perforated teeth (Brassempouy [78]); cut marks (Mladeč [79], La Crouzade [80], Les Rois [81]), burned bones and perforated teeth (Isturitz $[78,82])$ ) and Gravettian contexts (e.g. perforated teeth (Abri Pataud, layer 5 [83]; grooved teeth (Les Vachons [84], Dolní Věstonice [85])). In Western Europe, the most common funeral practice associated with the Gravettian techno-complex is primary burial. In most cases, the dead, whatever their age and sex, were deposited in the ground, with some ochre, objects and ornaments [86]. However, primary deposits of the body followed by a selection of bones for secondary burial, as observed in the Gravettian layer 6-1 at Buran-Kaya III, is also described in other Gravettian contexts, such as in layer $2(21,800+/-90$ BP$22470+/-90 \mathrm{BP}$, i.e. $25.85-27.12 \mathrm{ka}$ cal BP) from the Abri Pataud [87] or in the Abri de Fournol (A. Morala, com.pers). It therefore seems that there was some diversity in mortuary practices during the Gravettian.

\section{Conclusions}

Buran-Kaya III in Crimea is a key site for our understanding of the colonization of Europe by anatomically modern humans, as well as to assess their potential contemporaneity with the last Neanderthal populations in this region. The new radiocarbon dated sequence [44] casts doubt on the survival, as previously proposed, of a Neanderthal refuge zone in Crimea until $28 \mathrm{ka} \mathrm{BP}$ ago (35-32 ka cal BP), and shows that no Neanderthal settlement occurred after $35.6 \mathrm{ka}$ BP (39 ka cal BP). The settlement of anatomically modern humans associated with the Gravettian layers of BuranKaya III occurred under interstadial climatic conditions, which became progressively cooler and drier through the period of occupation [44]. The open and steppe-like periglacial environment, locally featuring a transition zone between steppes and mountains, provided a diversified faunal spectrum. Gravettian subsistence activities in Buran-Kaya III were mostly based on the use of Saiga antelope [42] during recurrent short-term occupation, for example for seasonal hunting or temporary butchery camps.

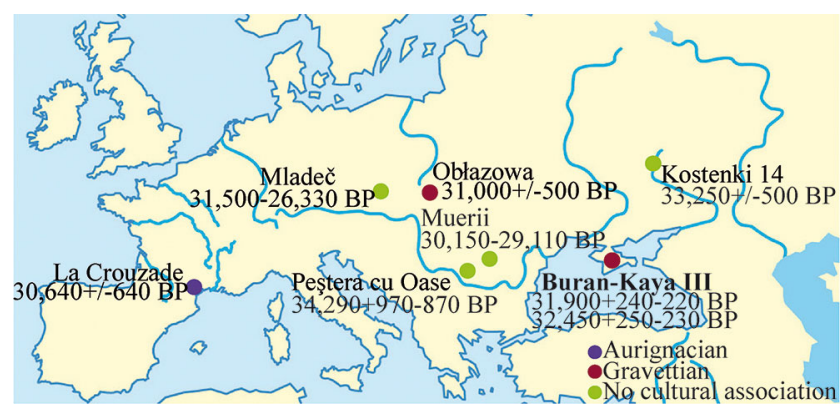

Fig 8 Map of the earliest anatomically modern humans directly dated by AMS ${ }^{14} \mathrm{C}$ (uncal BP) and their cultural context: BuranKaya III [43,44], La Crouzade [80], Koskenti 14 [5], Mladeč [88], Oblazowa Cave [55], Peștera cu Oase [2], Peștera Muerii [6, 89] / Localisation des plus anciens restes d'Hommes anatomiquement modernes dates directement par $\mathrm{AMS}^{14} \mathrm{C}$ (datations non calibrées BP) et leur cadre culturel : Buran Kaya III [43,44], La Crouzade [80], Koskenti 14 [5], Mladeč [88], Oblazowa [55], Peştera cu Oase [2], Peştera Muerii [6, 89].

The human remains unearthed from the Upper Palaeolithic layers have been directly dated to $37.8-36.5 \mathrm{ka}$ cal BP (layer 6-2 [44]) and 36.9-35.5 ka cal BP (layer 6-1 [43]). They are among the oldest direct evidence of anatomically modern humans in Europe in a well-documented archaeological context (Gravettian sensu lato), which is quite unique [43,44] (Figure 8). Based on taphonomical observations, the specimens from layer 6-1 represent the oldest Upper Palaeolithic modern humans from Eastern Europe with evidence of post-mortem treatment of the corpses.

Acknowledgements We would like to thank the editors of the BMSAP for accepting this paper for the special issue devoted to the $150^{\text {th }}$ anniversary of the Cro-Magnon discoveries, and the two reviewers for their helpful comments. We also thank the Fyssen Foundation and the French National Research Agency (ANR "Mammouths" Research Program No. ANR-05-JCJC-0240-01), the ATM Program on "Relations Sociétés-Nature dans le long terme" of the French National Natural History Museum (MNHN, Paris), the CNRS and the French Ministry of Foreign Affairs for their financial support. This paper was financially supported (MLG) by the Ministry of Culture of the Czech Republic under institutional financing for long-term conceptual development of research institutions (Moravian Museum, MK000094862). Thanks also to the National Academy of Sciences of Ukraine for permission to excavate at BuranKaya III, and to all the team members of the 2001 and 2009-2011 excavation seasons.

Conflict of interest: the authors do not have any conflict of interest to declare. 


\section{References}

1. Churchill SE, Smith FH (2000) Makers of the early Aurignacian of Europe. Yearbook of Phys Anthrop 43:61-115.

2. Trinkaus E, Moldovan O, Milota S, et al (2003) An Early Modern Human from the Peștera cu Oase, Romania. Proc Nat Acad Sci USA 100:11231-36.

3. Smith FH, Janković I, Karavanić I (2005) The assimilation model, modern human origins in Europe, and the extinctions of Neandertals. Quat Int 137:7-19.

4. Mellars P (2006) A new radiocarbon revolution and the dispersal of modern humans in Eurasia. Nature 439:931-5.

5. Marom A, McCullagh JSO, Higham TFG, et al (2012) Single amino acid radiocarbon dating of Upper Paleolithic modern humans. Proc Natl Acad Sci. U.S.A. 109:6878-81.

6. Soficaru A, Doboș A, Trinkaus E (2006) Early modern humans from the Peștera Muierii, Baia de Fier, Romania. Proc Natl Acad Sci USA 103:17196-201.

7. Anikovich MV, Sinitsyn AA, Hoffecker JF, et al (2007) Early Upper Paleolithic in Eastern Europe and implications for the dispersal of modern humans. Science 315:223-6.

8. Jöris O, Street M (2008) At the end of the ${ }^{14} \mathrm{C}$ time scale-the Middle to Upper Paleolithic record of western Eurasia. J Hum Evol 55:782-802.

9. Bailey SE, Weaver TM, Hublin J-J (2009) Who made the Aurignacian and other early Upper Paleolithic industries? J Hum Evol 57:11-26.

10. Hoffecker JF (2009). The spread of modern humans in Europe. Proc Nat Acad Sci USA 106:16040-5.

11. Rougier H (2008) Le peuplement de L'Europe par l'homme anatomiquement moderne: apport de la Peștera cu Oase (Roumanie). Annales de la Fondation Fyssen 28:75-89.

12. Trinkaus E, Soficaru A, Doboș A, et al (2009) Stable isotope for early Modern human diet in Southeastern Europe: Peștera cu oase, Peștera Muierii and Peștera Cioclovina Uscată. Materiale și cercetări archeologice V: 5-14.

13. Zilhão J, Davis SJM, Duarte C, et al (2010) Pego do Diabo (Loures, Portugal): Dating the emergence of Anatomical Modernity in Westernmost Eurasia. PLOS ONE 5(1):e8880.

14. Pinhasi R, Higham TFG, Golovanova L, et al (2011) Revised age of late Neanderthal occupation and the end of the Middle Paleolithic in the northern Caucasus. Proc Nat Acad Sci U.S.A 108 (21):8611-16.

15. Hublin J-J (2012) The earliest modern human colonization of Europe. Proc Nat Acad Sci USA 109:13471-72.

16. Hublin J-J (2013) The makers of the early Upper Paleolithic in Western Eurasia. In:Smith FH, Ahern JCM (eds.) The Origins of Modern Humans : Biology Reconsidered, Second ed. WileyBlackwell, Hoboken, New Jersey, pp. 223-52.

17. Wood RE, Barroso-Ruíz C, Caparrós M, et al (2013) Radiocarbon dating casts doubt on the late chronology of the Middle to Upper Palaeolithic transition in southern Iberia. Proc Nat Acad Sci USA 110(8):2781-86.

18. Benazzi S, Peresani M, Talamo S, et al (2014) A reassessment of the presumed Neandertal remains from San Bernardino Cave, Italy. J Hum Evol 66:89-94.

19. Higham T, Douka K, Wood R, et al (2014). The timing and spatiotemporal patterning of Neanderthal disappearance. Nature 512:306-309.

20. Kelso J, Prüfer K (2014) Ancient humans and the origin of modern humans. Curr Opin Genet Dev 29:133-8.

21. Pinhasi R., Meshveliani T., Matskevich, et al (2014) Satsurblia: New insights of human response and survival across the last glacial maximum in the Southern Caucasus. PLOS ONE 9:e111271.
22. Hublin J-J (2015) The modern human colonization of western Eurasia: when and where? Quat Sci Rev 118:194-210.

23. Pleurdeau D., Moncel MH., Pinhasi R. et al (2016) Bondi Cave and the Middle-Upper Palaeolithic Transition in western Georgia (South Caucasus). Quat Sci Rev 146 : 77-98.

24. Krause J, Fu Q, Good JM, Viola B et al (2010) The complete mitochondrial DNA genome of an unknown hominin from southern Siberia. Nature 464:894-7.

25. Green RE, Krause J, Briggs AW, et al (2010) A draft sequence of the Neandertal genome. Science 328:710-22.

26. Reich D, Green RE, Kircher M, et al (2010) Genetic history of an archaic hominin group from Denisova Cave in Siberia. Nature 468:1053-60.

27. Lalueza-Fox C, Gilbert MTP (2011) Paleogenomics of Archaic Hominins. Curr Biol 21:R1002-R1009.

28. Fu Q, Li H, Moorjani P, et al (2014) Genome sequence of a 45,000-year-old modern human from western Siberia. Nature 514:445-50.

29. Vernot B, Akey JM (2015) Complex history of admixture between modern humans and Neandertals. Am J Hum Genet 96: 448-53.

30. Sankararaman S, Mallick S, Patterson N, et al (2016) The combined landscape of Denisovan and Neanderthal ancestry in present-day humans. Curr Biol 26:1241-7.

31. Simonti CN, Vernot B, Bastarache L, et al (2016) The phenotypic legacy of admixture between modern humans and Neandertals. Science 351:737-41.

32. Browning SR, Browning BL, Zhou Y, et al (2018) Analysis of human sequence data reveals two pulses of archaic Denisovan admixture. Cell 173:53-61.

33. Marks AE (1998) A new Middle to Upper Paleolithic "transitional" assemblage from Buran-Kaya III, Level C, eastern Crimea: a preliminary report. In:Otte M (ed) Préhistoire d'Anatolie, Genèse de deux mondes. ERAUL 85, Liège. pp. 353-66.

34. Chabai V (2003) The chronological and industrial variability of the Middle to Upper Palaeolithic transition in Eastern Europe. In: Zilhão J, D'Errico F (eds). The chronology of the Aurignacian and of the transitional technocomplexes: dating, stratigraphies, cultural implications. Proceedings of Symposium 6.1, XIVe Congress of the UISPP, Instituto Portugues de Arqueologia, Trabalhos de Arqueologia 33, Lisboa, pp.71-86.

35. Chabai VP, Monigal K, Marks AE (2004) The Middle Paleolithic and Early Upper Paleolithic of Eastern Crimea. ERAUL 104, Liège. $482 \mathrm{p}$

36. Chabai VP (2001) The Late Middle and Early Upper Paleolithic in Crimea (Ukraine). In:Zilhão J, Aubry T, Carvalho AF (eds) Les premiers hommes modernes de la péninsule ibérique. Actes du colloque de la commission VIII de l'UISPP, Trabalhos de Arqueologia 17, Lisboa pp. 25-35.

37. Demidenko YE (2008) The Early and Mid-Upper Palaeolithic of the North Black Sea region: an overview. Quartär 55:99-114.

38. Marks A, Monigal K (2000) The Middle to Upper Paleolithic interface at Buran-Kaya-III, Eastern Crimea. In:Orschiedt J, Weniger GC (eds) Neanderthals and Modern Humans-Discussing the Transition: Central and Eastern Europe from 50,000-30,000 BP. Neanderthal Museum, Mettmann pp. 212-26.

39. Chabai VP (2012) The volcanic winter, Buran-Kaya cannibals and the fate of the last eastern European Neanderthals (In Ukrainian). Arkheologiya 3:5-26.

40. Yanevich A, Péan S, Crépin L et al (2009) Upper Palaeolithic settlements in Buran-Kaya 3 (Crimea, Ukraine): new interdisciplinary researches of the layers 5-2, 6-1 and 6-2. In:Chabai VP (ed) The top issues of the eastern european prehistoric archaeology. Donbas Archaeological Almanac 20, Donetsk pp. 187-202.

41. Yanevich A (2014) Les occupations gravettiennes de Buran-Kaya III (Crimée) : contexte archéologique. L'Anthropologie 118:554-66. 
42. Crépin L, Péan S, Lázničková-Galetová M (2014) Comportements de subsistance au Paléolithique supérieur en Crimée : analyse archéozoologique des couches 6-2, 6-1 et 5-2 de Buran-Kaya III. L'Anthropologie 118:584-98

43. Prat S, Péan SC, Crépin L, et al (2011) The Oldest Anatomically Modern Humans from Far Southeast Europe: Direct Dating, Culture and Behavior. PLOS ONE, e20834:1-13.

44. Péan S, Puaud S, Crépin L, et al (2013) The Middle to Upper Paleolithic sequence of Buran-Kaya III (Crimea, Ukraine): new stratigraphical, paleoenvironmental and chronological results. Radiocarbon, 55:1454-69.

45. Gerasimenko N (2004) Vegetational history of Buran- Kaya III. In: Chabai VP, Monigal K, Marks AE (eds) The Middle Paleolithic and Early Upper Paleolithic of Eastern Crimea. Liège: ERAUL, 104. pp 19-34.

46. Gerasimenko N (2007) Environmental changes in the Crimean Mountains during the last Interglacial-middle pleniglacial as recorded by pollen and lithopedology. Quat Int 164-165:207-20.

47. Devièse T, Karavanić I, Comeskeya D, et al (2017) Direct dating of Neanderthal remains from the site of Vindija Cave and implications for the Middle to Upper Paleolithic transition. Proc Nat Acad Sci U.S.A. 114:10606-11.

48. Adler DS, Bar-Yosef O, Belfer-Cohen A, et al (2008) Dating the demise: Neanderthal extinction and the establishment of modern humans in the southern Caucasus. J Hum Evol 55:817-33.

49. Posth C, Renaud G, MittnikA, et al (2016) Pleistocene mitochondrial genomes suggest a single major dispersal of non-africans and a late glacial population turnover in Europe. Curr Biol 26:827-33.

50. Nalawade-Chavan S, McCullagh J, Hedges R (2014) New Hydroxyproline Radiocarbon Dates from Sungir, Russia, Confirm Early Mid Upper Palaeolithic Burials in Eurasia. PLOS ONE 9: e76896

51. Svoboda (2006). The archaeological contexts of the human remains. In:Trinkaus E, Svoboda J (eds) Early Modern Human Evolution in Central Europe. The People of Dolní Věstonice and Pavlov. Oxford University Press, Oxford pp. 9-14.

52. Conard NJ, Bolus M (2003) Radiocarbon dating the appearance of modern humans and timing of cultural innovations in Europe: new results and new challenges. J Hum Evol 44:331-71.

53. Synitsyn AA, Praslov ND, Svezhentsev YS et al (1997) Radiouglerognaya khronologiya verkhnego paleolita Vostochnor" Evropy. In:Sinitsyn AA, Praslov ND (eds) Radiouglerodnaja khronologija paleolita Vostochnoj Evropy i Severnoj Azii. Problemy i perspektivy. Arkheologicheskie izyskaniya 52, IIMK RAN, St. Petersburg pp 21-66.

54. Haesaerts P, Damblon F, Bachner M, et al (1996) Revised stratigraphy and chronology of the Willendorf II sequence, Lower Austria. Arch Austr 80:25-42.

55. Valde-Nowak P, Nadachowski A, Madeyska T (2003) Obłazowa cave. Institute of Archaeology and Ethnology Polish Academy of Science, Krakow, 176 p.

56. Reimer PJ, Bard E, Bayliss A, et al (2013) IntCal13 and Marine13 Radiocarbon age calibration curves 0-50,000 years cal BP. Radiocarbon 55:1869-87.

57. Bonch-Osmolovskii GA (1934) Itogi izucheniya kpymskogo Paleolita. In:Butin VF et al, (eds) Trudy II mezhdunarodnoi" konferentsii assotsiatsii poizucheniyu chetvertichnogo perioda Evropy. Vypush V, NKTP, Leningrad-Moscow, pp 114-83.

58. Vlek E (1975) Morphology of the first metacarpal of Neandertal individuals from the Crimea. BMSAP 13(2):257-76.

59. Trinkaus E (2008) Kiik-Koba 2 and Neandertal axillary border ontogeny. Anthropol Sci 116:231-6.

60. Trinkaus E, Maley B, Buzhilova AP (2008) Brief communication: Paleopathology of the Kiik-Koba 1 Neandertal. Am J Phys Anthrop 137:106-12.
61. Kolosov YG, Stepanchuk VN, Chabai VP (1993) The Early Palaeolithic of the Crimea (in Russian). Naukova Dumka, Kiev.

62. Hoffecker JF (2002) Desolate Landscape: Ice-age settlement in Eastern Europe. New Jersey: Rutgers University Press. 298 p.

63. Klein RG (1965) The middle Palaeolithic of the Crimea. Arctic Anthropology III-1:34-68.

64. Demidenko YE, Chabai. VP, Otte M, et al (1998) Siuren-I, an aurignacian site in the Crimea (the investigations of the 19941996 field seasons). In:Otte M (ed) Préhistoire d'Anatolie, Genèse de deux mondes. ERAUL 85, Liège pp. 367-413.

65. Prat S. (2014) Stress physiologique et état de santé des plus anciens Hommes anatomiquement modernes du sud-est de l'Europe (données dentaires, couche 6-1, Buran-Kaya III, Crimée). L'anthropologie 118: 567-83.

66. Bailey S (2006) Beyond Shovel-Shaped Incisors: Neandertal Dental Morphology in a Comparative Context. Period Biol 108:253-67.

67. Brennan MU (1991) Health and disease in the Middle and Upper Paleolithic of southwestern France: A bioarcheological study. Ph. D. Thesis, New york University.

68. Skinner M (1996) Developmental stress in immature hominines from late Plesitocene Eurasia: evidence from enamel hypoplasia. J Archaeol Sci 23:833-52.

69. Teschler-Nicola M, Czerny C, Oliva M et al (2006) Pathological alterations and traumas in the human skeletal remains from Mladeč. In:Teschler-Nicola M (ed) Early Modern humans at the Moravian Gate. The Mladeč Caves and their Remains. SpringerVerlag, Wien, pp. 473-87.

70. Guatelli-Steinberg D, Buzhilova AP, Trinkaus E (2011) Developmental stress and survival among the Mid Upper Paleolithic Sunghir children: dental enamel hypoplasias of Sunghir 2 and 3. Int J Osteoarcheol 23:421-31.

71. Trinkaus E, Bailey SE, Rougier H (2013) The dental and alveolar remains of Oase 1 and 2. In: Trinkaus, E, Constantin S, Zilhão J (eds) Life and death at Peștera au Oase. A setting for Modern Human Emergence in Europe. Oxford University Press, New York, pp. 348-74.

72. Drucker DG, Naito YI, Péan S, et al (2017) Mammoth and plant in the diet of the oldest anatomically modern humans from far southest Europe. Scientific reports 7:6833.

73. Naito YI, Bocherens H, Chikaraishi Y, et al (2016) An overview of methods used for the detection of aquatic resource consumption by humans: Compound-specific delta N-15 analysis of amino acids in archaeological materials. J Archaeol Sci 6:720-32.

74. Bocherens H, Drucker DG, Billiou D, et al (2005) Isotopic evidence for diet and subsistence pattern of the Saint-Césaire I Neanderthal: review and use of a multi-source mixing model. J Hum Evol 49:71-87.

75. Wißing C, Rougier H, Crevecoeur I et al (2016) Isotopic evidence for dietary ecology of Late Neandertals in North-Western Europe. Quat Int 411:327-45.

76. Crépin L, Prat S, Péan S, et al (2012) Traitement du cadavre des plus anciens hommes anatomiquement modernes de l'extrême sud-est de l'Europe (Buran-Kaya III, Ukraine). BMSAP 22, suppl 1:11.

77. Villa P, Bouville C, Courtin J et al (1986) Cannibalism in the Neolithic. Science 233:431-7.

78. Henry-Gambier D, Maureille B, White W (2004) Vestiges humains des niveaux de l'Aurignacien ancien du site de Brassempouy (Landes). BMSAP 16:49-87.

79. Teschler-Nicola M (2006) Taphonomic aspects of the human remains from the Mladeč cave. In:Teschler-Nicola M (ed.) Early Modern humans at the Moravian Gate. The Mladeč Caves and their Remains. Springer-Verlag, Wien, pp. 75-92.

80. Henry-Gambier D, Sacchi D (2008) La Crouzade V-VI (Aude, France): un des plus anciens fossiles d'anatomie moderne en Europe occidentale. BMSAP 20:79-104. 
81. Ramirez-Rozzi F, d'Errico F, Vanhaeren M, et al (2009) Cutmarked human remains bearing Neandertal features and modern human remains associated with the Aurignacian at Les Rois. JASs $87: 153-85$.

82. White R, Normand C (2015) Les parures de l'Aurignacien ancien et archaïque de la grotte d'Isturitz: perspectives technologiques et régionales. $\mathrm{P} @$ lethnologie 7:140-66.

83. Vercoutère C, Giacobini G, Patou-Mathis M (2008) Une dent humaine perforée découverte en contexte Gravettien ancien à l'abri Pataud (Dordogne, France). L'Anthropologie 112(2):273-83.

84. Le Mort F (1981) Dégradations artificielles sur des os humains du Paléolithique. Thèse de $3 \mathrm{c}$ cycle, Université Pierre et Marie Curie, Paris, 204 p.

85. Svoboda J (2006) The Burials: Ritual and Taphonomy. In:Trinkaus E, Svoboda J (eds) Early Modern Human Evolution in Cen- tral Europe. The People of Dolní Věstonice and Pavlov. Oxford University Press pp. 15-26.

86. Henry-Gambier D (2008) Comportement des populations d'Europe au gravettien: pratiques funéraires et interprétations. Paleo $20: 165-204$.

87. Henry-Gambier D, Villotte S, Beauval C, et al (2013) Les vestiges humains : un assemblage original. In:Nespoulet R, Chiotti L, Henry-Gambier D (eds) Le Gravettien final de l'abri Pataud (Dordogne, France) Fouilles et études 2005-2009 - BAR International Series 2458, Oxford, pp.135-99.

88. Wild EM, Teschler-Nicola M, Kutschera W et al (2005) Direct dating of Early Upper Palaeolithic human remains from Mladeč. Nature 435:332-5.

89. Alexandrescu E, Olariu A, Skog G et al (2010) Os fossiles humains des grottes Muierii et Cioclovina, Roumanie. L'Anthropologie 114:341-53. 